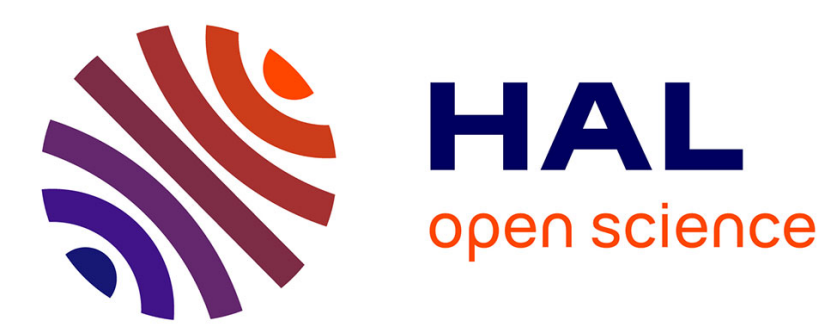

\title{
Heat-Resistance and Phase Composition of Ti-Si Coatings on Niobium
}

\author{
A. Kasatkin, S. Rybakov, G. Anurova
}

\section{To cite this version:}

A. Kasatkin, S. Rybakov, G. Anurova. Heat-Resistance and Phase Composition of Ti-Si Coatings on Niobium. Journal de Physique IV Proceedings, 1995, 05 (C5), pp.C5-823-C5-829. 10.1051/jphyscol:1995598 . jpa-00253962

\section{HAL Id: jpa-00253962 https://hal.science/jpa-00253962}

Submitted on 1 Jan 1995

HAL is a multi-disciplinary open access archive for the deposit and dissemination of scientific research documents, whether they are published or not. The documents may come from teaching and research institutions in France or abroad, or from public or private research centers.
L'archive ouverte pluridisciplinaire HAL, est destinée au dépôt et à la diffusion de documents scientifiques de niveau recherche, publiés ou non, émanant des établissements d'enseignement et de recherche français ou étrangers, des laboratoires publics ou privés. 


\title{
Heat-Resistance and Phase Composition of Ti-Si Coatings on Niobium
}

\author{
A.V. Kasatkin, S.U. Rybakov and G.M. Anurova
}

Institute of Physical Chemistry, Academy of Science of the Russia, Leninsky pr. 31, 117915 Moscow, Russia

\begin{abstract}
Abaract. A diffusion silioide ooatings on refraotory under thermal shook. A prospeotive method of improving their durability is the formation of multi-component ooatings. Ti is one of the widespread oomponents of suoh coatings.

In this work, process of simultaneous diffusion saturation of niobium by $\mathrm{Ti}$ and $\mathrm{Si}$ in powder mixtures has been investigated. The coatings oan be divided into two basio types: Mb-Ti solid solutions and $\mathrm{Nb}$ and $\mathrm{Ti}$ silioides. The coatings of the first type obtained in $\mathrm{Ti}-\mathrm{T} i_{5} S i_{3}$ powder mixtures. The complex silioide layers were observed in the paoks with higher Bilioon aotivity $\left(\mathrm{Ti}_{5} \mathrm{Si}_{3}-\right.$ TiSi and TiSi, $-T$ isi mixtures). The aotivities of Ti and $S i$ have been shown to be prinoipal oontrolling faotores in ooating phase in composition. The ooatings allows to inorease heat-resistanoe of the niobium and niobium alloys up to $2000^{\circ} \mathrm{C}(1,5$ hour $)$.
\end{abstract}

\section{INERODUOTION}

The temperature limit for exploitation of traditional diffusion costings on niobium and its alloys in oxidazing gaseous media does notexceed $1500^{\circ} \mathrm{C}$. It is well known that it a possible to inorease the limit temperature by combination of deposition methods, by elip-diffusion saturation method for an instanoe. It'B not always aoceptable however. Moreover, good ooating/base adhesion is not always attainable. So we supposed the coatings desoribed in work [1] to have some anomalous heat resistanoe for several oomposition area. This work investigates features of forming for Ti-si system ooatings, their oomposition and heat resistanoe in air as well. 


\section{EXPERTIENT}

Phase composition of powder diffusion souroes and coatings were studied by $X$-ray diffration analysis. The struoture and elemental composition of the ooatings were studied by mioroprobe analysiB and scanning eleotron mioroscopy. Cross-seotion profiles of elemental distributions in the diffusion zone were obtained using analytioal lines of $\mathrm{Ka}$-titanium, Ka-silioon and IR-niobium. Titanium silioides $\mathrm{Ti}_{5} \mathrm{Si} \mathrm{i}_{3}$. TiSi, TiSi, were used as the diffusion souroe, as well as equilibrium mixtures: $\mathrm{Ti}-\mathrm{Ti}_{8} \mathrm{Si} \mathrm{i}_{3}, \mathrm{Ti}_{8} \mathrm{Si} \mathrm{i}_{3}-\mathrm{TiSi}, \mathrm{TiSi}-\mathrm{Ti}$ with presence of fluoride aotivators: CaF $\mathrm{CgF}_{2}$, KP, Cuf 2 . The elemental composition of the gaturating mixture varied from $90 \mathrm{w. \%} \mathrm{Ti} \mathrm{-}$ $10 \mathrm{w} . \% \mathrm{Si}$ to $46 \% \mathrm{Ti}-54 \% \mathrm{Si}$ (stoiohiometry $\mathrm{TiSi}_{2}$ ), aotivities of the elements in the souroe be varied widely.

Heat-resistanoe of the ooatings were tested for coated wire No samples (diameter: 2mm, length: 50mm) on a direot ourrent heating plant. The temperature was measured with a oolor pyrometer SPECTROOPIR.

\section{III.RESULISS}

To ohoose the optimal regine of saturation of $\mathrm{Nb}$ with two elements simultaneousiy, a serie of experiments whith samples treated in Tisiz powder at $1000-1200^{\circ} \mathrm{C}$ was set. I was found that a layer of $\mathrm{NbSi}_{2}$ of variable thiokness, separated from the metal surface by a thin layer of $\mathrm{Nb}_{5} \mathrm{Si}_{\mathrm{a}}$, did always form. Ti was not found in the ooated samples, treated at $1000^{\circ} \mathrm{C}$. However, it started penetrating into $\mathrm{NbSi}_{2}$ at temperatures of $1100-1200^{\circ} \mathrm{C}$. The distribution of $\mathrm{Ti}$ in the $\mathrm{NbS} \mathrm{i}_{2}$ layer is uneven because of its preferential diffusion along the silioide grains' boundaries. The experiment's results show that Ti conoentrates on the grain boundries of $\mathrm{NbS}_{2}$ phase, slightly penetrating inside the grains too.

Sinoe the major interest was namely co-diffusion of $\mathrm{Ti}$ and $\mathrm{Si}$ into niobium, the saturation was performed at $1200^{\circ} \mathrm{C}$. It was shown that two areas on the oomposition range are to be distinguished: for the Ti-rioh mixture, the dominant process is titanization of niobium, while sinoe $\mathrm{si}$ content exoeeds $26 \%$, the growth of silicide-type ooatings takes place. Fig.1 shoes distribution of Ti,Si and $\mathrm{Nb}$ in a ooating formed at $1100^{\circ} \mathrm{C}$ ( $\mathrm{CaF}_{2}$ aotivator). A zone of solid solution $\mathrm{Nb}-$ Ti with slight presenoe of $s i(<0,5 \%)$ is formed on the sample surface. This effeot is attributed to the dependenoe of mutual difrusion coeffioient on the solution oomposition: No oonoentration being inoreased, D Nb-Tidecreases by several orders of magnitude, compare to the Ti-rioh zone [2]. Thus the inner part of the ooating aotually 


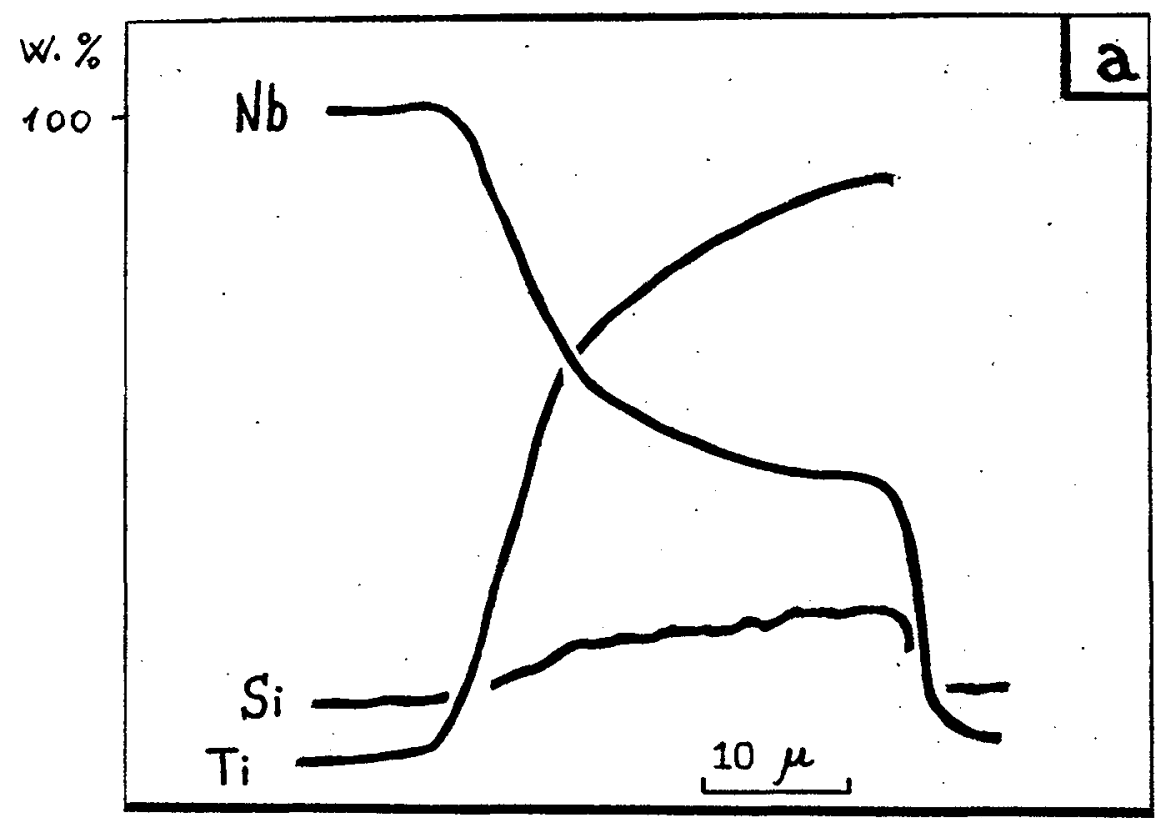

w. \%

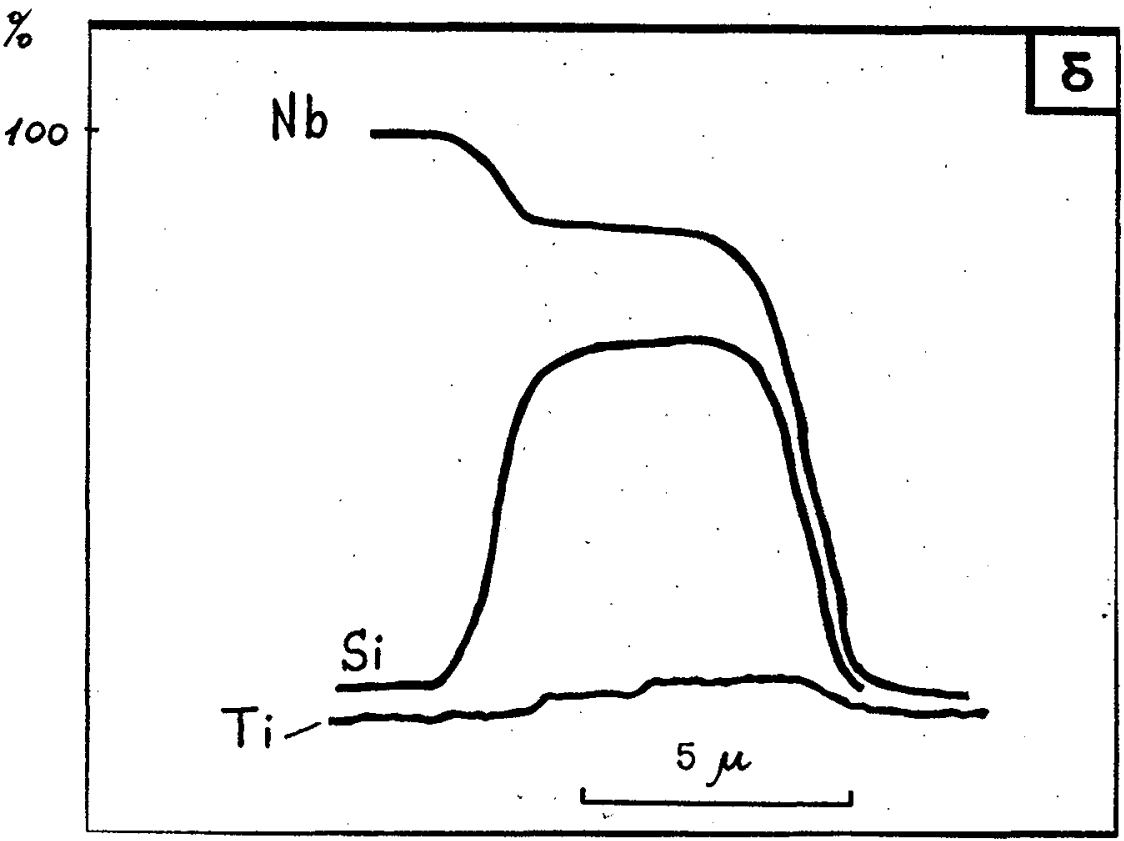

Pig. T. The depth distribution of the elements in diffusion zone after the treatment of niobium in

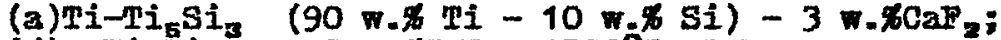

(6) Tis $i_{s}-3$ w. $\% 0$ ap $: 1300^{\circ} \mathrm{C}, 2$ hours 
plays the part of the diffusion barrier. The oonsequenoe is high (> 50\%) oonoentration of saturating element in the diffusion layer. This to oonfirms that $\mathrm{Ti}_{5} \mathrm{Si} \mathrm{i}_{3}$ in this oase almost an inert diluent. Diffusion saturation, performed with $\mathrm{Ti}_{\mathrm{5}} \mathrm{Si} \mathrm{i}_{3}$ powder, is aooompanied by $\mathrm{Nb}_{5} \mathrm{Si}_{3}$ growthing layer on the base metal Burfaoe and oharaoterised with minimal prooese epeed. The $T_{i}$ oonoentration in the coating is $<0,1 \%$. Obviously, Ti diffusion is being limited on the inner mase transfer Btage.

For titanium silioonizing of No in the mixtures with high aotivity of $\mathrm{Si}$ the growth of NbSi, alloyed by $\mathrm{Ti}$ may be observed. On the inner boundary of the oozting a thin layer of $\mathrm{Nb}_{8} \mathrm{Si}$ shase oooure. Due to quantitative analjsis results, Ti conoentration inoreases slightiy along the diffusion path from the souroe of TiSi $i_{2}$ to Tisi. The diffusion of Ti atoms in the NbSiz layer runs mostly along the grain boundaries. It should be mentioned that of the alloyed area is thinner than the total ooating for the samples treated with Tisi, Tisi-Tisiz, misi $_{2}$, (fig.2). X-ray analysis of the given samples showed the parameters of hexagonal lattioe of $\mathrm{Nb}$ alloyed with $\mathrm{Ti}$ to be: $a=0,4773 \pm 0,0002 \mathrm{~nm}, 0=0,6577 \pm 0,0002 \mathrm{~nm}$. The oomposition of the phase zone may be expressed as $\left(\mathrm{N}_{2}-\mathrm{X}\right.$ Tix)Siz. This means that eubstitution of Nb atoms with $\mathrm{Ti}_{i}$ in the NbSi, layer takes place. Thus, the Ti-alloyed coating areas are of disilioides solid solution based on NbSi, phase.

Treatment in the Tisis-Tisi mixture forms the most struoturally complex diffusion zone. The $\mathrm{Nb}_{5} \mathrm{Si}_{3}$ layer is extra-thiok beoause of some decrease of the Si aotivity in the source and the slowdown of gaseousphase transport of $\mathrm{si}$ to the sample surface. The Ti oonoentration of the outer two-phased layer (Bolid solution based on Ti and Nb disilioides) is about $15 \mathrm{w} . \%$. For conditions of 2-components diffusion saturation, the Gibbs Fhase Fule allows appearanoe and growth of a heterogeneous layer formed by the two phases. In the given oonditions this possibility is realized, the zone II (fig.2) of the phase (Tisi, ) appearing not only near the surface, but through the whole depth of the $\left(\mathrm{MbS} i_{2}-\mathrm{TiS} i_{2}\right)$ layer. Formation of guoh a two-phased layer contributeB to the primary diffusion of the alloying metal along the grain bondaries and forms the starting nonhomogenity of its distribution in the coating. Obviously, the acoumulation of Ti takes plase at first in the most defeotive areas of the lattioe (jumotions of the silioide grain boundaries is an example), whioh turms further to be the nuolea of the new phase.

A serie of experiments was performed to appreciate the heat-resistanoe of the optimal oomposition ooatings in air, the result being presented in the table. 


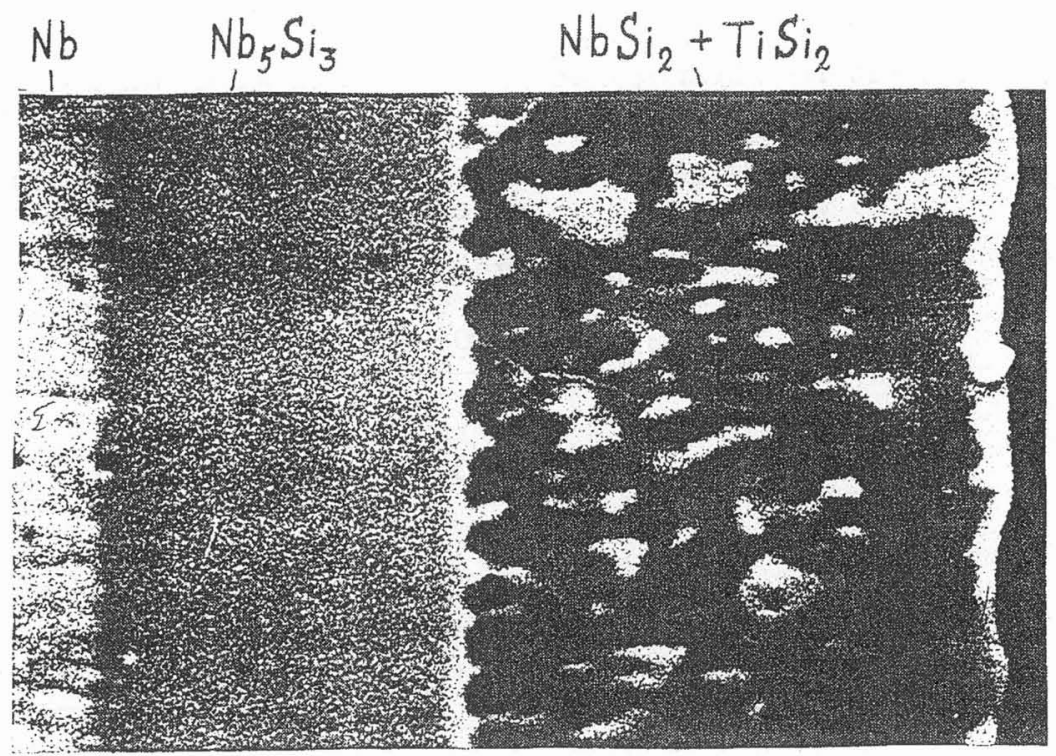

$\times 7000$

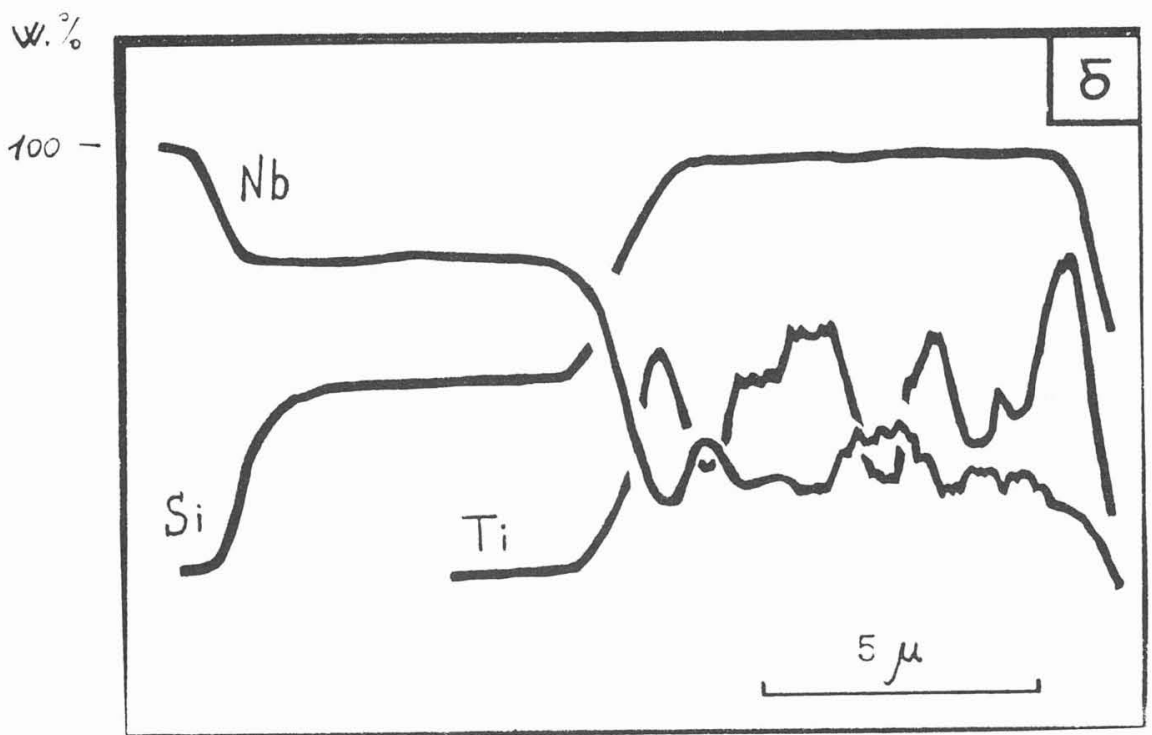

Fig.2. The etrueture of the oating (a) and the depth dietribution of the elements in the oosting (o)

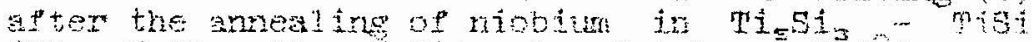

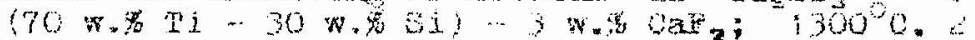
hourg 
Table

Tests for heat-resistanoe of Ti-Si-Bystem ooatings on niobium

\begin{tabular}{|c|c|c|c|}
\hline $\mathrm{NN}$ & $\begin{array}{l}\text { Thiokness of } \\
\text { the ooating, } \mu\end{array}$ & $\begin{array}{l}\text { Oxidation } \\
\text { temperature, }{ }^{\circ} \mathrm{C}\end{array}$ & $\begin{array}{l}\text { Exposition, } \\
\text { minutes }\end{array}$ \\
\hline \multirow[t]{2}{*}{1} & \multirow[t]{2}{*}{80} & 1750 & 23 \\
\hline & & 2000 & 85 \\
\hline \multirow[t]{5}{*}{2} & \multirow[t]{5}{*}{60} & 1750 & 9 \\
\hline & & 1800 & 5 \\
\hline & & 1900 & 8 \\
\hline & & 1950 & 5 \\
\hline & & 2000 & 25 \\
\hline \multirow[t]{5}{*}{3} & \multirow[t]{5}{*}{100} & 1750 & 10 \\
\hline & & 1800 & 10 \\
\hline & & 1850 & 5 \\
\hline & & 1950 & 5 \\
\hline & & 2000 & 80 \\
\hline
\end{tabular}

Thus, it is estabiished that the maximal temperature limit for the utilization of the coatinge of Ti-si-system on air is $2000^{\circ} \mathrm{C}$. The utilization time at $2000^{\circ} \mathrm{C}$ is $1-1,5 \mathrm{hrs}$. This is significantly more than for the known diffusion ooatinge, silioide type specifioally.

\section{CONHLUSTONS}

Investigations of the diffusion zone on $\mathrm{Nb}$ showed, that treatment in the mi-Tis $\mathrm{Si}_{3}$ leade to titanization of samples yielaing the solid solution of $\mathrm{Nb}-\mathrm{Ti}$. In a souroe with high aotivity of si the eilibide layer is being formed, its composition oorresponding to ( $\mathrm{Nb}, \mathrm{Ti}) \mathrm{Si} \mathrm{i}_{2}$, at the same time, depending on elemente aotivities alignment, the ooating may be monophaseous (Bolid solution based on $\mathrm{NbSi}_{2}$ ) of heterophazeous (solid on $\mathrm{NbSi}_{2}$ and $\mathrm{TiSi} i_{2}$ ). Ti diffusion into disilioide niobium layer may be observed at temperature higher than $1100^{\circ} \mathrm{C}$, running mostly along the grains bondaries, whioh leads to nonhomogeneous distribution of the alloying element even in a monophaseous coating.

The inorease of the temperature limit for utilization of Ti-si-Bystem ooatinge on niobium in air up to $2000^{\circ} \mathrm{C}$ is establiehed. 


\section{Reference}

[1] Tgirlin M.S.,Pgbakov S.t., J. Phya.II, 1 (1991) 02-735-C2-741. [2] Lrubinov V.D., Geld P.V., Sohveikir: G.P. et, al., Izv.AN SSSR Hetall:, N $4(1966), 132-138$. 